Тетяна ГРУЗЕВИЧ, orcid.org/0000-0003-2803-3659 вчитель англійської мови Хмельницької гімназії № 1 імені Володимира Красицького (Хмельницький, Україна) тvі_2016@ukr.net

\title{
СУТНІСТЬ ГРОМАДЯНСЬКОГО ВИХОВАННЯ УЧНІВ СТАРШИХ КЛАСІВ ЗАГАЛЬНООСВІТНІХ НАВЧАЛЬНИХ ЗАКЛАДІВ
}

\begin{abstract}
Стаття присвячена визначенню сутності громадянського виховання учнів старших класів загальноосвітніх навчальних закладів. Серед наукових категорій громадянського виховання учнів старших класів загальноосвітніх навчальних закладів завдяки використанню термінологічного методу автор виділяє такі: громадянин, громадянськість, виховання, громадянське виховання, держава, народ, наџія, громадянський обов'язок, громадянська відповідальність, громадянська активність, громадянська вихованість, громадянське мислення, громадянська культура, громадянське суспільство. Автор зазначає, щзо кожне покоління надає особливостей розумінню громадянськості, акцентуе увагу на сучасному тлумаченні изього поняття в суспільному та науковому просторі.

Громадянськість старшокласника автор визначає як складне особистісне утворення динамічного характеру, у змісті якого иілісно поєднуються емоційні, інтелектуальні, ціннісні та практичні аспекти життєдіяльності, спрямоване на позитивне ставлення до Батьківщзини, оточуючого суспільства та самого себе як громадянина держави.

Звертається увага на важливість визначення громадянського суспільства. У статті враховується неоднозначність підходів науковців як до трактування понять «виховання», «прочес виховання», «виховний процес», так i до їх співставлення. Прочес виховання у статті визначено як педагогічне явище, яке відбувається на основі двосторонньої активної взаємодії педагога (вихователя) $і$ (учня) вихования. За умови його грамотної організаиї результати мають пролонговану дію, оскільки досвід, який набувається, повністю виявляється не відразу.

Одним із напрямів виховання є громадянське. Сутність громадянського виховання учнів старших класів загальноосвітніх навчальних закладів автор розуміє як педагогічний проиес взаємодї учня і педагога, спрямований на набуття у сприятливих педагогічних умовах особистісних якостей, які характеризують ставлення учня до встановлених у державі порядків, законів, почуття власної гідності, знання і повагу до прав людини, чеснот громадянського суспільства і виявляються у свідомій, активній і відповідальній діяльності на основі засвоєних громадянських знань.

Автор зазначає, щзо розглянуті поняття виражають ставлення учнів до себе, до колективу, до навчання та виконання шкільних обов'язків, ставлення до суспільства, сформованість громадянських якостей.

Ключові слова: виховання, громадянин, громадянськість, громадянське виховання, учні старших класів, загальноосвітній навчальний заклад.
\end{abstract}

Tatiana GRUZEVICH, orcid.org/0000-0003-2803-3659 English Teacher Khmelnytsky Gymnasium № 1 named after Volodymyr Krasytsky (Khmelnytskyi, Ukraine) mvi_2016@ukr.net

\section{THE ESSENCE OF CIVIC EDUCATION OF SENIOR STUDENTS OF SECONDARY EDUCATIONAL INSTITUTIONS}

The article is devoted to defining the essence of civic education of high school students in secondary schools. Among the scientific categories of civic education of senior students of secondary schools through the use of the terminological method, the author identifies the following: citizen, citizenship, upbringing, civic education, state, people, nation, civic duty, civic responsibility, civic activism, civic education, civic thinking, civic culture, civil society. The author notes that each generation pays special attention to the understanding of citizenship, focuses on the modern interpretation of this concept in the social and scientific space.

The citizenship of a high school student is defined by the author as complex personal education of a dynamic nature, in the content of which integrally combines emotional, intellectual, value and practical aspects of life, aimed at a positive attitude towards the homeland, the surrounding society and himself as a citizen of the state.

Attention is drawn to the importance of defining civil society. The article takes into account the ambiguity of scientists' approaches to the interpretation of the concepts of "education", "education process", "educational process" and to their comparison. The process of education in the article is defined as a pedagogical phenomenon that occurs on the basis of 
bilateral active interaction of the teacher (educator) and (student) of the pupil, and provided its competent organization, the results have a prolonged effect, because the experience gained is not fully manifested immediately.

One of the areas of education is civic. The essence of civic education of senior students of secondary schools is understood by the author as pedagogical process of interaction between student and teacher, aimed at acquiring in favorable pedagogical conditions personal qualities that characterize the student's attitude to the rules established in the state, laws, self-esteem, knowledge and respect for human rights, civil society virtues and manifested in conscious, active and responsible activities on the basis of acquired civic knowledge.

The author notes that the considered concepts express the attitude of senior students to themselves, to the team, to learning and performing school duties, attitude to society, the formation of civic qualities.

Key words: education, citizen, citizenship, civic education, high school students, secondary school.

Постановка проблеми. Рівень громадянської культури сучасної молоді не завжди відповідає реальним потребам суспільства, яке ставить перед кожним своїм громадянином вимогу дотримання норм загальнолюдської моралі, шанобливого ставлення до національної культури, іiі відродження, поваги до історичних здобутків свого народу. Тому проблема пошуку шляхів і засобів національної освіти нині досить актуальна, а одним із пріоритетних іiї напрямів є громадянське виховання підростаючого покоління.

У документах, що регулюють державну освітню політику (Закони України «Про освіту», «Про загальну середню освіту», «Про позашкільну освіту», Указ Президента України «Про сприяння розвитку громадянського суспільства в Україні», Постанова Кабінету Міністрів України «Про основні орієнтири виховання учнів 1-11 класів загальноосвітніх навчальних закладів України», «Концепція державної сімейної політики»), значна роль приділяється завданням формування громадянина загалом і громадянського виховання учнів старших класів зокрема.

Аналіз досліджень. Різні аспекти проблеми громадянського виховання відображені у творчому доробку видатних педагогів і громадських діячів Г. Ващенка, М. Грушевського, А. Макаренка, В. Сухомлинського. У працях сучасних дослідників Р. Арцишевського, I. Беха, В. Борисова, П. Кендзьора, О. Кошолап, О. Пометун, Б. Ступарика, О. Сухомлинської, Г. Філіпчука, К. Чорної та інших наводяться розгорнуті визначення сутності громадянського виховання як педагогічної категорії.

Деякі автори виокремлюють структурні компоненти громадянського виховання (А. Бекірова, П. Вербицька, П. Волошин, К. Пекач). Дослідженню особливостей громадянського виховання молоді у різні історичні періоди було присвячено дисертаційні роботи О. Бенца, М. Заплетнюк, О. Кафарської, І. Кучинської, О. Рацула. Водночас не досить дослідженими залишаються питання визначення сутності громадянського виховання такої категорії як учні старших класів загальноосвітніх навчальних закладів.
Мета статті - визначення сутності громадянського виховання учнів старших класів загальноосвітніх навчальних закладів.

Виклад основного матеріалу. Використання термінологічного методу при формуванні й уточненні наукових категорій громадянського виховання учнів старших класів загальноосвітніх навчальних закладів дозволило виявити серед них такі: громадянин, громадянськість, виховання, громадянське виховання, держава, народ, нація, громадянський обов'язок, громадянська відповідальність, громадянська активність, громадянська вихованість, громадянське мислення, громадянська культура, громадянське суспільство. Окремі описані у педагогічній науці категорії та поняття було уточнено, деякі - було взято з наявним розумінням їх у науково-педагогічній літературі.

3 метою визначення сутності громадянського виховання учнів старших класів загальноосвітніх навчальних закладів проаналізуємо деякі тлумачення цього явища, запропоновані в науковій літературі. Сучасний тлумачний словник української мови тлумачить термін «громадянин» так: 1) особа, яка належить до постійного населення певної держави, користується іiї правами і виконує обов'язки, встановлені законами цієї держави; 2) дорослий чоловік; 3) той, хто підпорядковує особистісні інтереси громадським, служить Батьківщині; 4) член громади. Водночас «громадянськість» трактується як «усвідомлення кожним громадянином своїх прав і відповідальності за функції держави, яка має гарантувати ці права»; «громадянський - властивий свідомому громадянинові, спрямований на користь суспільства» (Дубічинський, 2009: 216).

На думку С. Гессена, «громадянськість» необхідно розглядати як частину загальної культури людини, як проміжний іiї шар, як право, що регулює зовнішні стосунки людей між собою і державою та забезпечує обов'язковість правових норм, організовує сукупність діяльності суспільства (Гессен, 1995: 226).

Кожне покоління надає особливостей розумінню громадянськості. В сучасному суспільному 
та науковому просторі межі громадянськості значно розширилися. Так, П. Волошин визначає «громадянськість як духовно-моральну цінність, світоглядно-психологічну характеристику людини, зумовлену ії державною самоідентифікацією, усвідомленням належності до конкретної країни». На думку вченого, з цим пов'язане ставлення людини до встановлених у державі порядків, законів, інституцій влади, почуття власної гідності, знання і повага до прав людини, чеснот громадянського суспільства, готовність і вміння дотримуватися обов'язків і користуватися правами (Волошин, 2009: 186).

На нашу думку, громадянськість старшокласникаєскладнимособистіснимутвореннямдинамічного характеру, у змісті якого цілісно поєднуються емоційні, інтелектуальні, ціннісні та практичні аспекти життєдіяльності, спрямованим на позитивне ставлення до Батьківщини, оточуючого суспільства та самого себе як громадянина держави.

Для нашого дослідження важливим є визначення громадянського суспільства. Сучасний тлумачний словник української мови визначає громадянське суспільство як суспільство високого статусу, яке створює разом із державою розвинені правові відносини, що насамперед спираються на визнання і повагу до гідності особистості як джерела прав людини (Дубічинський, 2009: 216).

У психолого-педагогічній літературі поняття «громадянське суспільство» трактується як «суспільство громадян, які мають невід'ємні права і свободи, сукупність інститутів і відносин, що $\epsilon$ наслідком діяльності громадян, спрямованої на задоволення їхніх інтересів і потреб; це політичний союз людей, які беруть участь у формуванні органів державної влади, впливають на визначення політики держави і здійснюють над нею контроль. Його в дійсності складають люди, які мають тверді й усвідомлені наміри служити інтересам свого суспільства» (Волошин, 2009: 187). Автори тлумачать поняття «громадянська позиція», «громадянська свідомість», «громадянська гідність», «громадянський обов'язок», «громадянська відповідальність», «громадянська мужність», засво$\epsilon$ ння яких $є$ важливим для визначення сутності громадянського виховання учнів старших класів загальноосвітніх навчальних закладів.

Щодо понять «виховання», «процес виховання», «виховний процес», то аналіз психологопедагогічної літератури свідчить про неоднозначність підходів науковців як до їх трактування, так і до їх співставлення. В українському педагогічному словнику С. Гончаренко виховання визначено як «процес цілеспрямованого, систематичного фор- мування особистості, зумовлений законами суспільного розвитку, дією багатьох об'єктивних i суб'єктивних факторів» (Гончаренко, 1997: 53).

Виховання - це головний компонент педагогічного процесу, надзвичайно складне соціальне явище, спрямоване на формування у вихованців наукового світогляду, особистісних рис громадянина України на основі відродження традицій національної свідомості, інтелектуального, професійного, морального, правового, фізичного, екологічного розвитку (Ягупов, 2002: 435). Процес - це зміна стану системи виховання як цілісного педагогічного явища, послідовне й поступове просування вперед для досягнення цілей виховання, розвитку і навчання, гармонійного формування і розвитку особистості українського громадянина (Ягупов, 2002: 435). Виховання віддалений процес просування до мети, формування особистості відповідно до суспільного ідеалу (Селиванов, 2000: 79).

Дослідник М. Фіцула визначає процес виховання як систему виховних заходів, спрямованих на формування всебічно і гармонійно розвиненої особистості (Фіцула, 2006: 232). Науковці I. Бех, О. Вишневський, І. Зязюн, О. Сухомлинська зазначають, що виховання полягає у перетворювальній діяльності вихователя, спрямованій на формування свідомості, світогляду, ціннісних орієнтацій, знань і способів діяльності особистості, що забезпечує іiї самовдосконалення. На їх думку, зміст виховання необхідно наповнювати вічними, високими ідеалами, які б задовольняли як потреби особистості, так і запити суспільства та інтереси держави й нації (Сойчук, 2016: 26-27). Ми погоджуємося із наведеними визначеннями. Додамо, що процес виховання - це педагогічне явище, яке відбувається на основі двосторонньої активної взаємодії педагога (вихователя) і (учня) вихованця. За умови його грамотної організації результати мають пролонговану дію, оскільки досвід, який набувається, відразу повністю не виявляється.

Одним із напрямів виховання є громадянське. Громадянське виховання - це процес формування громадянськості (Волошин, 2009: 187). Нами було взято до уваги думку О. Вишневського, що «специфічною метою українського виховання є прищеплення державницького світогляду, коли свою долю та особисте щастя людина пов'язує з упорядкованою державою, яка має міцні моральні підвалини і добрі та шановані людьми закони» (Вишневський, 2006: 145).

В Законі України «Про повну загальну середню освіту» визначено, що «виховний процес $є$ невід'ємним складником освітнього процесу 
у закладах освіти і має грунтуватися на загальнолюдських цінностях, культурних цінностях українського народу, цінностях громадянського (вільного демократичного) суспільства, принципах верховенства права, дотримання прав і свобод людини і громадянина та спрямовуватися на формування:

1) відповідальних і чесних громадян, які здатні до свідомого суспільного вибору та спрямування своєї діяльності на користь іншим людям і суспільству;

2) поваги до гідності, прав, свобод, законних інтересів людини і громадянина; нетерпимості до приниження честі та гідності людини, фізичного або психологічного насильства, а також до дискримінації за будь-якою ознакою;

3) патріотизму, поваги до державної мови та державних символів України, поваги та дбайливого ставлення до національних, історичних, культурних цінностей, нематеріальної культурної спадщини українського народу, усвідомленого обов'язку захищати у разі потреби суверенітет i територіальну цілісність України;

4) усвідомленої потреби в дотриманні Конституції та законів України, нетерпимості до їх порушення, виявів корупції та порушень академічної доброчесності;

5) громадянської культури та культури демократії тощо».

Сутність громадянського виховання учнів старших класів загальноосвітніх навчальних закладів ми розуміємо як педагогічний процес взаємодії учня і педагога, спрямований на набуття у сприятливих педагогічних умовах особистісних якостей, які характеризують ставлення учня до встановлених у державі порядків, законів, почуття власної гідності, знання і повагу до прав людини, чеснот громадянського суспільства і виявляються у свідомій, активній і відповідальній діяльності на основі засвоєних громадянських знань.

Одним із чинників громадянського виховання учнів старших класів є громадянський світогляд, який є частиною світогляду народного (національного). За визначенням Д. Чижевського: «Народний світогляд $є$ національно зумовленим становиськом народу до світу та життя. Він виявляється і в тому, що цей народ у світі любить, чого в житті він уникає, що в людині найвище оцінює, до чого ставиться негативно» (Чижевський, 1992: 171).

Світогляд - це сукупність загальних переконань, які стосуються світу, людини та суспільства, місця майбутнього офіцера у світі, сенсу його життя та які визначають його ідеали, ціннісні орієнтації, життєві настанови, впливають на формування готовності до майбутньої професійної діяль- ності. В українців свій самобутній світогляд, який розкриває ставлення до людини, природи, пояснює сенс життя, місце людини в ньому. В українців власне розуміння таких життєво-важливих понять як світ, людина, народ, духовність, нація, любов, віра і праця (Мірошніченко, 2012: 93).

Протягом розвитку людського суспільства народний світогляд не залишався незмінним. 3 плином часу під впливом об'єктивних i суб'єктивних чинників (географічних, історичних, культурологічних, соціологічних) він зазнав значних змін. Народний світогляд впливає на формування світогляду кожної особистості української держави (Гевко, 2003: 31). Урахування національного світогляду є необхідним в освітньому процесі загальноосвітнього навчального закладу.

Формування світогляду учнів старших класів, у якому переважатимуть засади громадянськості, $\epsilon$ одним із завдань освітнього процесу загальноосвітніх навчальних закладів. Вплив суспільства, держави, школи на особистість учня відбувається опосередковано через складну систему соціальних посередників: сім'ю, шкільне освітнє середовище, педагогів, колектив, неформальну групу (організацію), засоби масової інформації, які виступають суб'єктами соціально-психологічної підтримки розвитку, виховання й освіти.

Зі змістової точки зору громадянське виховання можна розглядати як становлення громадянської (національної) свідомості, засвоєння громадянських (національних) цінностей. Громадянська свідомість - це свідоме розуміння й внутрішнє прийняття особистістю того факту, що вона належить до певного державного соціуму. Це засвоєне i прийняте людиною особистісне ставлення до певного суспільства, держави, яке виражається у прагненні активно діяти для його захисту, охорони, розвитку (Волошин, 2009: 188). Для того, щоб громадянське виховання стало основою всієї виховної системи, потрібні систематичні й глибокі зусилля держави, суспільства, сім’ї, шкільного середовища.

У контексті нашого дослідження доречно звернутися до поняття «громадянського обов'язку». Під обов'язком прийнято розуміти те, що необхідно безвідмовно виконувати згідно з вимогами суспільства або з огляду на власне переконання. На думку С. Сливки, його необхідно розглядати як зовнішній та внутрішній імператив (наказ) (Сливка, 2001: 30-31).

Громадянський обов'язок означає, що особистість усвідомлює і переживає свою багатосторонню залежність від держави, ті завдання, які поставила перед нею держава і які вона повинна 
реалізувати у своїй діяльності. Громадянська відповідальність - почуття, яке виникає в результаті того, як особистість відчуває себе щодо виконання або невиконання своїх громадянських обов'язків; переживання відповідальності за наслідки власної громадянської діяльності. Громадянська мужність - це здатність особистості рішуче і цілеспрямовано діяти, активно відстоювати національнодержавно-суспільні цілі (Волошин, 2009: 188).

Нам імпонує визначення поняття «відповідальність» у тлумачному словнику психологічних термінів як здатності особистості розуміти відповідність результатів своїх дій поставленим цілям, прийнятим у суспільстві або в колективі нормам, у результаті чого виникає почуття співучасті в загальній справі, а при невідповідальності-почуття невиконаного обов'язку (Бродовська, 2005: 25). У нашому розумінні відповідальність $є$ сукупністю суспільно-необхідних норм і правил для представників певного суспільства, яких останні мають обов'язково дотримуватися.

Учені розглядають такі види відповідальності: соціальну, політичну, професійну, правову, навчальну, трудову, які пов'язують з об'єктом відповідальності. Досліджуючи активізацію людського фактору, В. Бакіров звертає увагу на відповідальність як поняття, що відображає ступінь відповідності дій соціальних суб'єктів взаємним вимогам, а також історичним соціальним нормам і суспільним інтересам. Автор поділяє відповідальність на відносно самостійні види: юридичну, економічну, політичну, партійну, професійну та екологічну (Бакиров, 1988: 212). За рівнем соціальної організації він виокремлює суспільну, державну, групову та колективну відповідальність. На нашу думку, громадянська відповідальність може належати до кожної із зазначених груп, також можливим $\epsilon$ існування індивідуальної громадянської відповідальності.

Громадянську відповідальність ми відносимо до сукупності моральних, психологічних і духовних якостей (Durr, 2005: 65), яка дає змогу відповідати за громадянську діяльність учня як вияв його громадянської вихованості. Результатом громадянського виховання учня має бути громадянська вихованість, яка полягає у сформованості громадянських якостей, громадянської свідомості та на її основі - громадянської культури. Розглянуті поняття виражають ставлення учнів старших класів загальноосвітніх навчальних закладів до себе, до колективу, до навчання та виконання шкільних обов'язків, до суспільства, сформованість громадянських якостей.

Висновки. Отже, сутність громадянського виховання учнів старших класів загальноосвітніх навчальних закладів ми розуміємо як педагогічний процес взаємодії учня і педагога, спрямований на набуття у сприятливих педагогічних умовах особистісних якостей, які характеризують ставлення учня до встановлених у державі порядків, законів, почуття власної гідності, знання і повагу до прав людини, чеснот громадянського суспільства і виявляються у свідомій, активній і відповідальній діяльності на основі засвоєних громадянських знань. Результатом громадянського виховання учнів старших класів загальноосвітніх навчальних закладів $€$ їхня громадянська вихованість.

Вивчення сутності та структури понять «громадянська вихованість», «громадянська культура», «громадянська компетентність» становить перспективу подальших наукових пошуків з окресленої проблеми.

\section{СПИСОК ВИКОРИСТАНИХ ДЖЕРЕЛ}

1. Сучасний тлумачний словник української мови: 10000 слів / за заг. ред. В. В. Дубічинського. Х. : «Школа», 2009. $1008 \mathrm{c}$.

2. Гессен С. Й. Основы педагогики. Введение в прикладную философию. Берлин : «Слово», 1923. Составление: М. : Школа-Пресс, 1995. 448 с.

3. Громадянське виховання молодших школярів : хрестоматія. Укл. П. Волошин. Умань : РВЦ «Софія», 2009. $196 \mathrm{c}$.

4. Гончаренко С. У. Український педагогічний словник. Київ : Либідь, 1997. 376 с.

5. Ягупов В. Педагогіка : навчальний посібник. К. : Либідь, 2002. 560 с.

6. Селиванов В. С. Основы общей педагогики: теория и методика воспитания : учеб. пособие для студ. высш. пед. учеб. заведений. М. : Академия, 2000. 336 с.

7. Фіцула М. Педагогіка вищої школи : навчальний посібник. К. : Академвидав, 2006. 352 с.

8. Сойчук Р. Л. Виховання національного самоствердження в учнівської молоді : монографія. Рівне : О. Зень, 2016. $416 \mathrm{c}$.

9. Вишневський О. Теоретичні основи сучасної української педагогіки. Дрогобич : Коло, 2006. 326 с.

10. Чижевський Д. Нариси з історії філософії на Україні. К. : Орій, 1992. 228 с.

11. Мірошніченко В. І. Система патріотичного виховання майбутніх офіцерів-прикордонників : монографія. Хмельницький : Вид-во НАДПСУ, 2012. 376 с.

12. Гевко О. І. Національно-патріотичне виховання студентів вищих педагогічних закладів засобами декоративно-ужиткового мистецтва : дис. канд. пед. наук. К., 2003. 210 с. 
13. Сливка С. С. Юридична деонтологія : підручник. К. : Атіка, 2001. 304 с.

14. Бродовська В. Й. Тлумачний словник психологічних термінів. К. : Професіонал, 2005. 224 с.

15. Бакиров В. С. Ценностное сознание и активизация человеческого фактора. Х., 1988. 248 с.

16. Durr K. The School: a Democratic Learning Community. The All-European Study on Pupils' Participation in School. Strasbourg : Council of Europe. 2005, 124.

\section{REFERENCES}

1. Suchasnyi tlumachnyi slovnyk ukrainskoi movy (2009): [Modern explanatory dictionary of the Ukrainian language] 10000 sliv / za zah. red. V. V. Dubichynskoho. Kh. : "Shkola", 2009. 1008 s. [in Ukrainian].

2. Hessen C. Y. (1923) Osnovы pedahohyky. Vvedenye v prykladnuiu fylosofyiu. [Fundamentals of Pedagogy. Introduction to applied philosophy] Berlyn : "Slovo", 1923. Sostavlenye: M. : Shkola-Press, 1995. 448 s. [in Russian].

3. Hromadianske vykhovannia molodshykh shkoliariv (2009). [Civic education of junior schoolchildren] : khrestomatiia. Ukl. P. Voloshyn. Uman : RVTs "Sofiia", 2009. 196 s. [in Ukrainian].

4. Honcharenko S. U. (1997). Ukrainskyi pedahohichnyi slovnyk. [Ukrainian pedagogical dictionary]. Kyiv : Lybid, 1997. 376 s. [in Ukrainian].

5. Yahupov V. (2002) Pedahohika [Pedagogy] : navchalnyi posibnyk. K. : Lybid, 2002. 560 s. [in Ukrainian].

6. Selyvanov V. S. (2000). Osnovы obshchei pedahohyky: teoryia y metodyka vospytanyia [Fundamentals of General Pedagogy: Theory and Methods of Education] : ucheb. posobye dlia stud. vyssh. ped. ucheb. zavedenyi. M. : Akademyia, 2000. 336 s. [in Russian].

7. Fitsula M. (2006) Pedahohika vyshchoi shkoly [Pedagogy of high school] : navchalnyi posibnyk. K. : Akademvydav, 2006. 352 s. [in Ukrainian].

8. Soichuk R. L. (2016). Vykhovannia natsionalnoho samostverdzhennia v uchnivskoi molodi [Education of national self-affirmation in student youth] : monohrafiia. Rivne : O. Zen, 2016. 416 s. [in Ukrainian].

9. Vyshnevskyi O. (2006). Teoretychni osnovy suchasnoi ukrainskoi pedahohiky. [Theoretical foundations of modern Ukrainian pedagogy]. Drohobych : Kolo, 2006. 326 s. [in Ukrainian].

10. Chyzhevskyi D. (1992). Narysy z istorii filosofii na Ukraini. [Essays on the history of philosophy in Ukraine]. K. : Orii, 1992. 228 s. [in Ukrainian].

11. Miroshnichenko V. I. (2012). Systema patriotychnoho vykhovannia maibutnikh ofitseriv-prykordonnykiv. [The system of patriotic education of future border officers] : monohrafiia. Khmelnytskyi : Vyd-vo NADPSU, 2012. 376 s. [in Ukrainian].

12. Hevko O. I. (2003). Natsionalno-patriotychne vykhovannia studentiv vyshchykh pedahohichnykh zakladiv zasobamy dekoratyvno-uzhytkovoho mystetstva. [National-patriotic education of students of higher pedagogical institutions by means of decorative and applied arts] : dys. kand. ped. nauk. K., 2003. 210 s. [in Ukrainian].

13. Slyvka S. S. (2001). Yurydychna deontolohiia [Legal deontology] : pidruchnyk. K. : Atika, 2001.304 s. [in Ukrainian].

14. Brodovska V. Y. (2005). Tlumachnyi slovnyk psykholohichnykh terminiv. [Explanatory dictionary of psychological terms]. K. : Profesional, 2005. 224 s. [in Ukrainian].

15. Bakyrov V. S. (1988). Tsennostnoe soznanye y aktyvyzatsyia chelovecheskoho faktora. [Value consciousness and activation of the human factor]. Kh., 1988. 248 s. [in Russian].

16. Durr K. (2005). The School: a Democratic Learning Community. The All-European Study on Pupils' Participation in School. Strasbourg : Council of Europe. 2005, 124 s. [in English]. 